\title{
Synergy and Energy, Public Libraries and Programming
}

George B. Viele

Across the country local governments are reacting to and reeling from federal cuts in some programs and elimination of others. Citizens have been and are still forming organizations to gain strength and support for their demands for fewer taxes. Thus, major service institutions in our society such as schools, hospitals, universities, and local governments are enmeshed in financial crises. The public library across the land finds itself in a no-win situation. It has shrinking budgets intensified by its purchses of materials whose costs are inflated. Because of these conditions, the public library's future cannot be guaranteed. It may be an endangered species plagued with many serious problems.

Of the multiple problems facing public libraries today, some have their roots in the fact that the public library has lost its way. Confusion regarding its purposes and responsibilities exists everywhere and perhaps more so in the minds of public librarians than anywhere else. This is borne out by the fact that the public library in most instances and in most communities has become a many-faceted service organization. It tries to be all things for all people. Thus, a pressing question today for librarians and boards of turstees is, Can public libraries survive today without clearly defining their role in society?

The purpose of this article is not so much to argue against programming as it is to clarify the proper role of the public library based on its origin and the pressing needs of the world's society today.

This aim will be accomplished by (1) discussing the origin of the public library in relation to the socio-economic thermodynamic theory of how and why organizations begin; (2) touching briefly on the role of the public library in light of socio-economic thermodynamics and sound business practices; and (3) showing the public library's role in relation to society's needs.

George B. Viele is Director, Greensboro Public Library.

\section{Synergy and Origin of the Species Bibliotheca Publicus}

Socio-economic "thermodynamics" encom passes many principles or ideas. One of these provides us the basis for recognizing that individuals as a group will form an organization when they recognize or realize that a synergis tic effect will result from their cooperative efforts or actions. ${ }^{1}$

Synergism is defined by Webster as coopera. tive action producing a total or final effect which is greater than the sum of the parts taken separately. Another way of looking at synergism is that it provides unique and beneficial results which come from a combined or group effort which could not have been realized by just the efforts of one person.

For example, in 1833 in the town of Peterborough, N.H., the town assembly authorized that its state share of the Literary Fund be used to purchase books for a town library that would be free to all citizens in the town. The state of New Hampshire in 1849 passed into law "An Act Providing for the Establishment of Public Libraries." It was in the City of Boston that the synergistic effect became clear and visible. The well-known names of Joshua Bates, Josiah Quincy, Jr., George Ticknor, and Edward Everett are linked with the beginnings of the Boston Public Library.

The public library development literature is replete with example after example of individuals in communities working together to starta public library. Truly, they realized that only through their combined efforts and financial support could public libraries be established. These libraries would provide better informational and educational opportunities to all citizens than could private or social libraries.

Advocates of public libraries in the nineteenth century were motivated by a multiplicity of forces. Some of these were (1) scholarly research and the lack of adequate library resources; (2) local pride of cultural heritage as reflected in the science and literary culture (especially in Boston) of New England; and (3) 
the social importance of universal public education. Although the latter force was not as significant a force as the others, most citizens everywhere believed in the possibility of selfeducation and that reading promotes morality. ${ }^{2}$ Thus, public libraries grew out of need and collective synergistic action of community leaders, self-appointed or otherwise.

No wonder then that in 1852 the Boston

Public Library Board of Trustees' report read:

\begin{abstract}
It has been rightly judged that-under political, social, and religious institutions like ours-it is of paramount importance that the means of general information should be so diffused that the largest number of persons should be induced to read and understand questions going down to the very foundations of social order, which are constantly presenting themselves, and which we as a people are constantly required to decide, and do decide, either ignorantly or wisely.
\end{abstract}

\section{Energy, Programming, and the Role of the Public Library}

Organizatioinal theory focuses on two fundamental and related questions. In the preceding section discussion centered on the question "Why does an organizatioin come into being?" In this section the topical question is: "What is the basic objective of an organization -any organization?

Again, from socio-economic "thermodynamics" we obtain the answer. Lloyd stated it well: "The comprehensive objective of an organization is to maximize the synergistic effect." 6 Expressing it another way, synergistic action leads to a higher state or order of potential. This concept is of great significance and importance to library directors and boards of trustees. Why this is will be explained later.

Synergy and energy as words are similar in appearance. Removing the consonants " $\mathrm{s}$ " and " $y$ " and adding the vowel " $e$ " will change synergy to energy. While the words are similar in appearance their enactments produce totally different results. The expenditure of energy produces entrophy whereas synergism expended produces synthesis. Relate this to public library activities.

Programming has been defined as "a planned activity by library personnel designed to inform, educate, or culturally enrich the public." Programming includes story hours, book talks, plant sitting, lending of tools, and other diverse activities. Programming is energy in action.

Thus, to maximize their synergistic effect, public library managers must first discontinue programming and then review what is the basic objective of their organization. Peter Drucker emphasized repeatedly in his writings that "Only a clear definition of the mission and purposes of the business makes possible clear and realistic business objectives." In proclaiming these as the foundation for organizational priorities and strategies Drucker says that "Strategy determines what the key activities are in a given business and strategy requires that management knows what its business is and what it should be."

Thus, the two-part question arises: What is the purpose of the public library? and How can the library maximize its synergistic effect? The purpose of the library is to provide books. It maximizes its synergistic effect by bringing together people and books-a synthesis of the reader ultimately seeking out the thoughts and ideas of the writer or author.

Edward Sydney says that the informal study of books is adult education. He argues that "The organization of lectures and other adult educational activities ... is not properly part of the library service." ${ }^{10}$ He claims, though, that it is the library's responsibility to provide books for these purposes. ${ }^{11} \mathrm{I}$, for one, wholeheartedly agree.

From a business standpoint, the public library must be dealt with as an economic institution. As the libraries' budgets shrink from both inflation and actual budgets cuts, it is imperative that library managers trim their multifarious services and re-establish or develop those strategies which will increase their library book stocks. From personal experience and observation, I have observed the continuing decrease of the percent of library budgets allocated for books. More and more the personnel and fringe benefit portions of the budget increase at the expense of materials.

Programming of any type is labor intensive. Programming is energy in action and therefore, by reducing or eliminating programming, libraries can maximize their synergistic effect of providing more books and materials relevant to the needs of their library public.

This can only be accomplished by library managers applying sound business principles which include defining their mission and learning through analysis the library needs of their community. The goals and objectives as Drucker said will enable them to develop strategies that will in the long run (1) reduce the size of their staffs and (2) increase book and resource materials substantially. 


\section{The Public Library Role and Society's Needs}

Today's public library is caught up in an economically and socially declining society which no longer necessarily respects the public library or values it for what it represents. For that matter, our society has lost its respect for educational excellence, scholarly research, local pride of its cultural heritage, and in some cases, the desire to pay taxes to provide and support the major service organizations mentioned in the opening paragraph. Little wonder the foundations of public library services are shaking, trembling, and sometimes crumbling in the economic and societal chaos of today's modern world. The public library faces threats that imperil its present existence and cloud the certainty of its future primarily because of conditions or forces which are beyond its control.

Even more serious than the fate of public libraries is the question of survival of the human race and the world as we know it. According to Lewis E. Lloyd, "The critical problem of world survival in this atomic age has its roots in the fact that technical progress has so far outdistanced our understanding of how to live and work together effectively."12

However, there is still time for citizens of this country and the world to change its bent on self destruction, its possible destiny of being a burning atomic sphere. The accumulated wisdom of the human race is locked in the books written by man. Even for those in remote areas of the world, their access to the world's best thought is through books available at their local public library.

Tompkins wrote that the public library's

unique position as the only non-partisan agency for the free distribution of books to people of all ages, educational levels, national and racial origins, and religious beliefs gives it exceptional opportunities to identify interests, stir curiosity and raise a desire for information on subjects and problems important to individuals and to society. ${ }^{1 .}$
Through proper strategies, library administrators can emphasize in their library policies those procedures that (1) will allow the book stock to grow in quantity and quality and (2) will increase the availability of books to their readers through better circulation procedures and better utilization of their facility or building.

By maximizing the synergistic effect of concentrating their efforts and monies on selecting books for circulation and making them easily available, the managers of public libraries will have allowed their services to rise to their highest state of order or potential. The public library directors have the opportunity to put the public library on the cutting edge of the future of the world. The final question is whether they will return the public library to its proper role of providing books or will they allow the public library to fade away in desuetude while the library public waits in disquietude.

\section{References}

1. Lewis E. Lloyd, "Origins and Objectives of Organizations" in Organization Theory in Industrial Practice, ed. Mason Haire (New York: John Wiley and Sons, 1962), p. 28. 2. Jesse H. Shera, Foundation of the Public Library (Chicago: The University of Chicago Press, 1949), pp. 206-228.

3. "Report of the Trustees of the Public Library of the City of Boston, July 1852" in "United States of America" by Miriam D. Tompkins in Adult Education Activities for Public Libraries by Carl Thomsen, Edward Sydney, and Miriam D. Tompkins (UNESCO, 1950), p. 57.

4. Lloyd, p. 29.

5. Ibid.

6. Ibid.

7. "A Practical Approach to Programming," Adult Services in Action, No. 1 (Chicago: American Library Association, 1982), p. 1 .

8. Peter F. Drucker, Management: Tasks, Responsibilities, and Practices (New York: Harper \& Row, 1974), p. 75.

9. Ibid.

10. "United Kingdom" by Edward Sydney in Adult Educa. tion Activities for Public Libraries by Carl Thomsen, Edward Sydney, and Miriam D. Tompkins (UNESCO, 1950), p. 29. 11. Ibid.

12. Lloyd, p. 28.

13. "United States of America" by Miriam D. Tompkins in Adult Education Activities for Public Libraries by Carl Thomsen, Edward Sydney, and Miriam D. Tomkins (UNESCO, 1950), p. 57. 